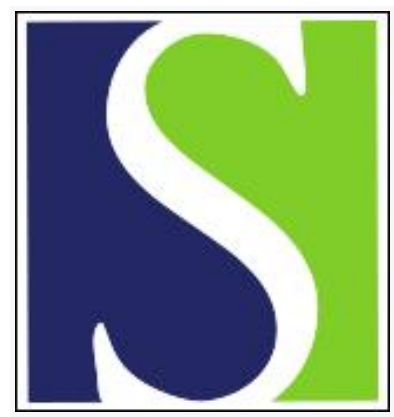

Scand J Work Environ Health 2013;39(2):134-143

https://doi.org/10.5271/sjweh.3321

Published online: 07 Sep 2012, Issue date: 01 Mar 2013

The effect of ill health and socioeconomic status on labor force exit and re-employment: a prospective study with ten years follow-up in the Netherlands

by Schuring M, Robroek SJW, Otten Ferdy WJ, Arts CH, Burdorf A

Affiliation: Department of Public Health, Erasmus MC, PO Box 2040, 3000 CA Rotterdam, The Netherlands. m.schuring@erasmusmc.nl

Refers to the following texts of the Journal: 2004;30(4):287-292

2008;34(4):235-238 2011;37(6):473-480

The following articles refer to this text: 2013;39(2):121-124;

2013;39(3):233-240; 2013;39(6):609-617; 2014;40(2):186-194; 2014;40(4):331-333; 2014;40(5):473-482; 2015;41(3):299-311; 2015;41(5):441-450; 2016;42(3):209-216; 2017;43(1):24-33; 2017;43(4):307-315; 2017;43(6):540-549; 2018;44(5):496-502; 2019;45(4):346-355; 2019;45(5):514-519; 2020;46(1):77-84; 2021;47(3):208-216; 2021;47(3):224-232; 2022;48(4):283-292; 2023;49(2):117-125

Key terms: disability pension; early retirement; ill health; labor force exit; prospective study; re-employment; return to work; socioeconomic status; The Netherlands; unemployment

This article in PubMed: www.ncbi.nlm.nih.gov/pubmed/22961587

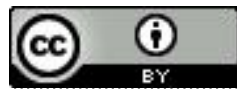




\title{
The effect of ill health and socioeconomic status on labor force exit and re- employment: a prospective study with ten years follow-up in the Netherlands
}

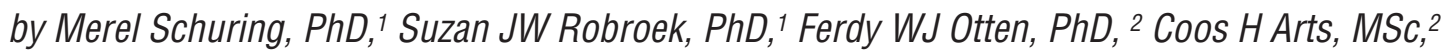 \\ Alex Burdorf, $P h D^{1}$
}

\begin{abstract}
Schuring M, Robroek SJW, Otten FWJ, Arts CH, Burdorf A. The effect of ill health and socioeconomic status on labor force exit and re-employment: a prospective study with ten years follow-up in the Netherlands. Scand J Work Environ Health. 2013;39(2):134-143. doi:10.5271/sjweh.3321
\end{abstract}

\begin{abstract}
Objectives The aim of this study was to investigate the effect of ill health and socioeconomic status on labor force exit due to unemployment, early retirement, disability pension, or becoming economically inactive. A secondary objective was to investigate the effect of ill health and socioeconomic status on return to work.

Methods A representative sample of the Dutch working population ( $\mathrm{N}=15$ 152) was selected for a prospective study with ten years follow-up (93917 person-years). Perceived health and individual and household characteristics were measured at baseline with the Permanent Quality of Life Survey (POLS) during 1999-2002. Statistics Netherlands ascertained employment status monthly from January 1999 to December 2008. Cox proportional hazards analyses were used to determine the factors that predicted labor force exit and return to work.
\end{abstract}

Results Ill health increased the likelihood of labor force exit into unemployment [hazard ratio (HR) 1.89], disability pension (HR 6.39), and early retirement (HR 1.20), but was not a determinant of becoming economically inactive (HR 1.07). Workers with low socioeconomic status were, even after adjusting for ill health, more likely to leave the labor force due to unemployment, disability pension, and economic inactivity. Workers with ill health at baseline were less likely to return to work after unemployment (HR 0.75 ) or disability pension (HR 0.62). Socioeconomic status did not influence re-employment.

Conclusions Ill health is an important determinant for entering and maintaining paid employment. Workers with lower education were at increased risk for health-based selection out of paid employment. Policies to improve labor force participation, especially among low socioeconomic level workers, should protect workers with health problems against exclusion from the labor force.

Key terms disability pension; early retirement; return to work; unemployment.

In many industrialized countries, the population is ageing due to increasing life expectancy and falling birth rates (1). These demographic changes are bringing about a shift in the ratio of workers to retirees that will lead to a relative shortage of active workers (2). As a consequence, it is important to increase labor force participation. In the Netherlands, policies are developed to promote re-employment of non-employed persons. In addition, measures are undertaken to encourage older workers to remain in the labor force longer. Clearly, the success of these policies will depend on having a better understanding of the particular role of health on entering and remaining in paid employment.
There is ample evidence that ill health may cause exit from the labor force (3-7). The association between health and employment may not be similar across all socioeconomic groups (8). Although life expectancy is increasing, it is not equally distributed in society. Persons with a lower level of education, a lower occupational class, or a lower level of income tend to die at a younger age and have, within their shorter lives, a higher prevalence of all kinds of health problems. This leads to large differences between socioeconomic groups in the number of years a person can expect to live in good health. As a result, individuals with a low socioeconomic status are more likely to be faced with health problems

1 Department of Public Health, Erasmus University Medical Centre, Rotterdam, the Netherlands.

2 Statistics Netherlands, Heerlen, The Netherlands

Correspondence to: Merel Schuring, Department of Public Health, Erasmus MC, PO Box 2040, 3000 CA Rotterdam, The Netherlands. [E-mail: m.schuring@erasmusmc.nl] 
before the retirement age. In addition, there may be differences between socioeconomic groups with respect to the pathway that a person with health problems takes out of the workforce. Workers may leave the workforce due to unemployment, early retirement, disability pension, or by becoming economically inactive.

Among those employed, the risk of exclusion from working life as a result of disability pension varies considerably by education, occupation, and income. A low level of education, occupational status, and income seem to be strong determinants of disability in both genders (9-14). A recent Norwegian study (15) showed that there was a socioeconomic gradient in disability pension corresponding to socioeconomic gradients in health. However, ill health seemed to account for only a small part of the increased risk of disability pension among those with a low educational level.

Van den Berg et al's systematic review (16) showed that poor health was an important factor in early retirement. A longitudinal study based on five annual waves of the European Household Panel Survey showed that socioeconomic status influenced the effects of health on transitions between paid employment and various forms of non-employment. Poor health was a risk factor for becoming unemployed or retiring early, especially among highly educated workers (17). A cross-sectional study among older employees in the healthcare sector in Sweden showed that economic incentives and legal regulations were important factors for older workers in planning their retirement and their beliefs as to whether they were able and wanted to work until 65 years or beyond (18).

After exiting the labor force, a substantial proportion of subjects may return to work. The likelihood of reemployment may also depend on health, socioeconomic status, and the pathway through which a person left the labor force. Few studies have explored the influence of ill health and socioeconomic status on the re-employment of persons who left the workforce (19-21).

Against this background, the aim of this study was to investigate the effect of ill health and socioeconomic position on labor force exit due to unemployment, early retirement, disability pension, or becoming economically inactive. The secondary aim of this study was to investigate the effect of ill health and socioeconomic position on re-employment after an individual has left the workforce through one of these four mechanisms.

\section{Methods}

\section{Study population}

The study population was based on an annual Statistics Netherlands' national survey, the Permanent Survey on
Living Conditions (POLS), carried out in the period 1999-2002. The POLS response rate was approximately $60-65 \%$ each year for questionnaires with complete information. The POLS was conducted among a random sample of the non-institutionalized population in the Netherlands (22). During the four consecutive years (1999-2002), in total 39220 persons participated. First, the POLS data were enriched with information on main components of income (ie, social benefits, pensions, and gross wages) derived from Dutch tax registers and stored in a huge omnibus database, the so-called Sociaal Statistisch Bestand (SSB) of Statistics Netherlands. Second, the POLS data were longitudinally matched with the SSB information on the main source of income for each subsequent month during a follow-up period of ten years (1999-2008). For the purposes of this study, we selected 15152 individuals aged between 18-64 years who were in paid employment for $>12$ hours per week in the Netherlands at the time of the health survey. The total follow-up time comprised 93917 person-years. In the Netherlands, there are no possibilities by law or in collective labor agreements to officially retire before the age of 50 . Thus, for the analyses on early retirement, the study population was further restricted to those individuals aged between 45-64 years at the time of the health survey who were continuously employed or left the labor force due to early retirement during the follow-up period of the study $(\mathrm{N}=3751)$.

\section{Sociodemographic variables}

The POLS comprised questions on individual and household characteristics, perceived health, and employment status. Individual characteristics included age, sex, and education. Household characteristics included marital status and household composition. Additionally, the enrichment of POLS with income components provided proxies for both gross personal and household income for the employees at the baseline measurement. Persons were classified according to their level of educational attainment into low (pre-primary, primary, and lower secondary), intermediate (upper-secondary) and high (postsecondary) education. Information on marital status was used to distinguish individuals married or living together from others. Household and personal income were categorized into four percentile groups $\left(<25^{\text {th }}, 25-50^{\text {th }}\right.$, $50-75^{\text {th }},>75$ ), relative to the income distribution of the study sample. If the personal income of a subject was $>75 \%$ of the household income, the subject was defined as the breadwinner within the household.

\section{Health measure}

Self-reported health was measured with one general question asking individuals to rate their overall health 
on a five-point scale. The five answer categories were "very good", "good", "fair", "poor" and "very poor". Those reporting less than "good health" were defined as having a poor health (23).

\section{Employment status}

Information on employment status was derived from the Dutch tax register as provided by Statistics Netherlands. Employment status was divided into five mutually exclusive categories: employment, unemployment, early retirement, disability pension, and economic inactivity. Employed persons had their main source of income through paid employment or having their own business. Unemployed persons received unemployment benefits or social security benefits. Persons with a disability pension received a disability pension for $>50 \%$ of their personal income. Early-retired persons received a pension as their main source of income before they reached the age of 65 years. Economically inactive persons did not have a personal income or benefits.

Re-employment was defined as becoming employed for $>3$ months after a period of non-employment (unemployment, disability pension, early retirement, or economic inactivity) of $>1$ month.

\section{Statistical analysis}

To calculate rates of displacement from the workforce, the number of displacements were divided by personyears at risk in the study population.

The effect of ill health and socioeconomic characteristics on labor force exit due to unemployment, disability pension, early retirement, or becoming economically inactive was investigated with Cox proportional hazards analysis. A person was censored at the moment the person reached the statutory retirement age of 65 years, died, left the country, started with education, at the end of the follow-up period (December 2008), or at first exit from the labor market. Independent factors were individual and household characteristics and perceived health. Variables were coded in such a manner that a hazard ratio (HR) $>1$ indicated an increased likelihood of labor force exit. Interactions between socioeconomic status (education or income) and health were of specific interest. The Cox proportional hazards analyses were conducted in two steps; the first model included health and demographic variables while the second model additionally adjusted for socioeconomic variables.

Determinants of re-employment after leaving the workforce due to unemployment or disability pension were also investigated with Cox proportional hazards analysis. At the end of the follow-up period (December 2008), all persons who had not re-entered the labor force were censored. Independent factors were individual and household characteristics and perceived health at baseline. Variables were coded in such a manner that a HR $>1$ indicated an increased likelihood of re-employment.

\section{Results}

The study population consisted of 15152 Dutch employees with a follow-up time of 93917 person-years. Figure 1 shows that becoming economically inactive was the most prevalent pathway out of the labor force $(\mathrm{N}=2411$; 25.67 per 1000 person-years), followed by unemployment ( $\mathrm{N}=1264 ; 13.46$ per 1000 person-years) and early retirement ( $\mathrm{N}=961 ; 10.23$ per 1000 person-years). Leaving the labor force due to disability pension was the less frequent route ( $\mathrm{N}=398 ; 4.24$ per 1000 person-years).

Table 1 shows that a low educational level [HR $1.64,95 \%$ confidence interval $(95 \% \mathrm{CI}) 1.38-1.94]$, low personal income (HR 1.73, 95\% CI 1.41-2.13) and poor health (HR 1.89, 95\% CI 1.63-2.18) increased the likelihood of becoming unemployed. In the multivariate model, education and income both had an independent influence on the likelihood of becoming unemployed. In addition, older workers and breadwinners (personal income $>75 \%$ of household income) were more likely to become unemployed, whereas workers living with a partner were less likely to leave the labor force due to unemployment.

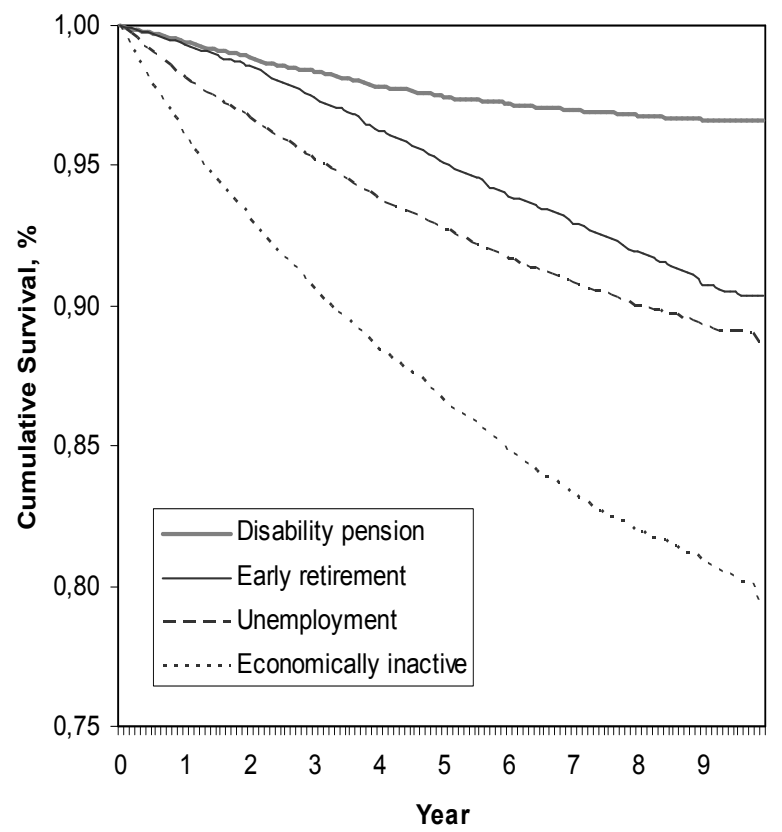

Figure 1. Labor force exit due to disability pension, early retirement, unemployment or becoming economically inactive in a dynamic cohort with enrolment during 1999-2002 and follow-up until 2008 in the Netherlands. 
Table 1. Cox proportional hazards analysis of the influence of individual characteristics and self-perceived health on the likelihood of unemployment among persons who were continuously employed or became unemployed $(\mathrm{N}=11382)$ during a follow-up period of ten years. [HR=hazard ratio; $95 \% \mathrm{Cl}=95 \%$ confidence interval.]

\begin{tabular}{|c|c|c|c|c|c|c|c|c|}
\hline & \multirow[b]{2}{*}{$\mathrm{N}$} & \multirow[b]{2}{*}{$\%$} & \multicolumn{2}{|c|}{ Model 1 a Univariate } & \multicolumn{2}{|c|}{ Model 2 b Multivariate } & \multicolumn{2}{|c|}{ Model 3 c Multivariate } \\
\hline & & & $\mathrm{HR}$ & $95 \% \mathrm{Cl}$ & $\mathrm{HR}$ & $95 \% \mathrm{Cl}$ & $\mathrm{HR}$ & $95 \% \mathrm{Cl}$ \\
\hline \multicolumn{8}{|l|}{ Age (years) } & $1.63-2.18$ \\
\hline $18-34$ & 4311 & 38 & 1 & & 1 & & 1 & \\
\hline $35-44$ & 3859 & 34 & 0.76 & $0.66-0.87$ & 0.76 & $0.66-0.87$ & 0.76 & $0.65-0.88$ \\
\hline $45-54$ & 2810 & 25 & 1.02 & $0.89-1.17$ & 0.99 & $0.86-1.14$ & 1.01 & $0.86-1.17$ \\
\hline $55-64$ & 402 & 4 & 2.47 & $1.96-3.11$ & 2.40 & $1.91-3.03$ & 2.30 & $1.80-2.92$ \\
\hline Female & 4568 & 40 & 1.26 & $1.13-1.41$ & 1.24 & $1.11-1.39$ & 1.09 & $0.95-1.25$ \\
\hline \multicolumn{8}{|l|}{ Educational level } & $0.63-0.87$ \\
\hline High & 3186 & 28 & 1 & & & & 1 & \\
\hline Intermediate & 5621 & 49 & 1.21 & $1.05-1.40$ & & & 1.09 & $0.94-1.27$ \\
\hline Low & 2532 & 22 & 1.95 & $1.67-2.28$ & & & 1.64 & $1.38-1.95$ \\
\hline \multicolumn{9}{|l|}{ Personal income } \\
\hline$>75 \%$ & & & 1 & & & & 1 & \\
\hline $75-50 \%$ & & & 1.08 & $0.91-1.28$ & & & 0.98 & $0.82-1.17$ \\
\hline $50-25 \%$ & & & 1.39 & $1.18-1.63$ & & & 1.21 & $1.00-1.47$ \\
\hline$<25 \%$ & & & 1.95 & $1.67-2.29$ & & & 1.73 & $1.41-2.13$ \\
\hline \multicolumn{9}{|c|}{ Personal share of household income } \\
\hline
\end{tabular}

${ }^{a}$ All variables separately (unadjusted model).

${ }^{\mathrm{b}}$ Adjusted for health and demographic variables.

${ }^{\mathrm{c}}$ Adjusted for health, demographic variables, and socioeconomic indicators.

Similarly to unemployment, a low educational level (HR 1.47, 95\% CI 1.08-2.00) and a low personal income (HR 1.57, 95\% CI 1.07-2.29) increased the likelihood of labor force exit due to disability pension (table 2). In addition, females (HR 1.57, 95\% CI 1.24-2.0.) and older workers (HR 8.29, 95\% CI 5.92-11.63) also had an increased likelihood of exiting the labor force for this reason. Poor health had the largest influence (HR 7.00, 95\% CI 5.73-8.55, multivariate model 2) on leaving the labor force, which was reduced slightly after adjusting for socioeconomic status (HR 6.39, 95\% CI 5.20-7.86, multivariate model 3).

Table 3 shows that a low educational level (HR 1.33, 95\% CI 1.10-1.61) and poor health (HR 1.20, 95\% CI 1.02-1.41) increased the likelihood of labor force exit due to early retirement, whereas a low income decreased the likelihood of early retirement (HR $0.55,95 \%$ CI 0.42-0.71). Older workers, females, workers living with a partner, and breadwinners were more likely to retire early.

The majority of persons who left the workforce subsequently became economically inactive. The likelihood of becoming economically inactive was increased by a low educational level (HR 1.44, 95\% CI 1.26-1.63) and low income (HR 2.08, 95\% CI 1.78-2.43). However, health did not influence the likelihood of becoming economically inactive (table 4). Workers who were not living with a partner, females, and younger (18-34 years) and older (55-64 years) age groups, were more likely to leave the labor force for economic inactivity.
For every pathway out of the labor force (unemployment, disability pension, early retirement, economic inactivity), interactions between socioeconomic status (education or income) and health did not contribute statistically significantly to the model (data not shown). These results suggest that the effects of poor health on labor force exit were not influenced by socioeconomic status.

Of the 5034 employees who left the labor force, 3070 persons re-entered the labor force during the follow-up period of the study. Figure 2 shows that economically inactive ( $\mathrm{N}=1887 ; 540$ per 1000 person-years) and unemployed persons $(\mathrm{N}=931 ; 425$ per 1000 personyears) were more likely to re-enter the workforce than persons with a disability pension $(\mathrm{N}=178 ; 136$ per 1000 person-years) or early-retired persons $(\mathrm{N}=74 ; 20$ per 1000 person-years, data not shown). Figure 2 also shows that the likelihood of re-employment was highest among persons who recently left the labor force and decreased with increasing duration of the non-employment period down to approximately zero after seven years of nonemployment.

Table 5 shows that the likelihood of re-entering the labor force gradually declined with increasing age. A poor health negatively influenced re-employment after unemployment or disability pension, but did not influence reemployment after being economically inactive. Married persons were more likely to re-enter paid employment after disability pension and less likely to re-enter paid employment after being economically inactive. 
Table 2. Cox proportional hazards analysis of the influence of individual characteristics and self-perceived health on the likelihood of disability pension among persons who were continuously employed or left the labor force for disability pension ( $N=10516)$ during a follow-up period of ten years. [HR=hazard ratio; $95 \% \mathrm{Cl}=95 \%$ confidence interval.]

\begin{tabular}{|c|c|c|c|c|c|c|c|c|}
\hline & \multirow[b]{2}{*}{$\mathrm{N}$} & \multirow[b]{2}{*}{$\%$} & \multicolumn{2}{|c|}{ Model $1^{\text {a }}$ Univariate } & \multicolumn{2}{|c|}{ Model $2{ }^{\mathrm{b}}$ Multivariate } & \multicolumn{2}{|c|}{ Model 3 c Multivariate } \\
\hline & & & $\mathrm{HR}$ & $95 \% \mathrm{Cl}$ & $\mathrm{HR}$ & $95 \% \mathrm{Cl}$ & $\mathrm{HR}$ & $95 \% \mathrm{Cl}$ \\
\hline Perceived poor health & 1279 & 12 & 8.61 & $7.07-10.48$ & 7.00 & $5.73-8.55$ & 6.39 & $5.20-7.86$ \\
\hline \multicolumn{9}{|l|}{ Age (years) } \\
\hline 18-34 & 3903 & 37 & 1 & & 1 & & 1 & \\
\hline $35-44$ & 3600 & 34 & 1.17 & $0.87-1.57$ & 1.05 & $0.78-1.42$ & & \\
\hline $45-54$ & 2630 & 25 & 2.77 & $2.12-3.62$ & 2.23 & $1.71-2.92$ & & \\
\hline $55-64$ & 383 & 4 & 10.73 & $7.77-14.82$ & 7.92 & $5.70-11.0$ & & \\
\hline Female & 4201 & 40 & 1.62 & $1.33-1.97$ & 1.66 & $1.36-2.03$ & 1.57 & $1.24-2.01$ \\
\hline Married/living together & 8979 & 85 & 0.67 & $0.52-0.86$ & 0.75 & $0.58-0.97$ & 0.79 & $0.59-1.06$ \\
\hline \multicolumn{9}{|l|}{ Educational level } \\
\hline High & 2992 & 29 & 1 & & & & 1 & \\
\hline Intermediate & 5209 & 50 & 1.16 & $0.89-1.51$ & & & 1.09 & $0.82-1.44$ \\
\hline Low & 2265 & 22 & 2.25 & $1.72-2.95$ & & & 1.47 & $1.08-2.00$ \\
\hline \multicolumn{9}{|l|}{ Personal income } \\
\hline$>75 \%$ & & & 1 & & & & 1 & \\
\hline $75-50 \%$ & & & 1.34 & $0.99-1.82$ & & & 1.28 & $0.92-1.78$ \\
\hline $50-25 \%$ & & & 1.81 & $1.35-2.42$ & & & 1.57 & $1.11-2.21$ \\
\hline$<25 \%$ & & & 1.84 & $1.36-2.48$ & & & 1.57 & $1.07-2.29$ \\
\hline \multicolumn{9}{|c|}{ Personal share of household income } \\
\hline$\geq 75 \%$ & 3433 & 33 & 1.10 & $0.90-1.36$ & & & 1.12 & $0.87-1.45$ \\
\hline
\end{tabular}

a All variables separately (unadjusted model).

${ }^{b}$ Adjusted for health and demographic variables.

${ }^{c}$ Adjusted for health, demographic variables, and socioeconomic indicators.

Table 3. Cox proportional hazards analysis of the influence of individual characteristics and self-perceived health on the likelihood of early retirement among persons who were $\geq 45$ years old and continuously employed or left the labor force for early retirement ( $N=3751)$ during a follow-up period of ten years. [HR=hazard ratio; $95 \% \mathrm{Cl}=95 \%$ confidence interval.]

\begin{tabular}{|c|c|c|c|c|c|c|c|c|}
\hline & \multirow[b]{2}{*}{ N } & \multirow[b]{2}{*}{$\%$} & \multicolumn{2}{|c|}{ Model 1 a Univariate } & \multicolumn{2}{|c|}{ Model $2{ }^{\mathrm{b}}$ Multivariate } & \multicolumn{2}{|c|}{ Model $3^{\circ}$ Multivariate } \\
\hline & & & $\mathrm{HR}$ & $95 \% \mathrm{Cl}$ & $\mathrm{HR}$ & $95 \% \mathrm{Cl}$ & $\mathrm{HR}$ & $95 \% \mathrm{Cl}$ \\
\hline Perceived poor health & 587 & 16 & 1.32 & $1.12-1.55$ & 1.22 & $1.04-1.44$ & 1.20 & $1.02-1.41$ \\
\hline \multicolumn{9}{|l|}{ Age (years) } \\
\hline $45-54$ & 2823 & 75 & 1 & & 1 & & 1 & \\
\hline $55-64$ & 928 & 25 & 12.96 & $11.30-14.87$ & 12.90 & $11.23-14.82$ & 13.35 & $11.60-15.36$ \\
\hline Female & 1287 & 34 & 0.76 & $0.66-0.87$ & 0.92 & $0.80-1.06$ & 1.36 & $1.14-1.62$ \\
\hline Married/living together & 3303 & 88 & 0.98 & $0.80-1.19$ & 1.05 & $0.86-1.28$ & 1.26 & $1.01-1.57$ \\
\hline \multicolumn{9}{|l|}{ Educational level } \\
\hline High & 1101 & 29 & 1 & & & & 1 & \\
\hline Intermediate & 1583 & 42 & 1.02 & $0.87-1.19$ & & & 1.13 & $0.96-1.33$ \\
\hline Low & 1040 & 28 & 1.23 & $1.04-1.45$ & & & 1.33 & $1.10-1.61$ \\
\hline \multicolumn{9}{|l|}{ Personal income } \\
\hline$>75 \%$ & 1556 & 42 & 1 & & & & 1 & \\
\hline $75-50 \%$ & 948 & 25 & 1.06 & $0.91-1.23$ & & & 1.04 & $0.88-1.23$ \\
\hline $50-25 \%$ & 631 & 17 & 0.72 & $0.59-0.87$ & & & 0.67 & $0.54-0.84$ \\
\hline$<25 \%$ & 613 & 16 & 0.63 & $0.51-0.77$ & & & 0.55 & $0.42-0.71$ \\
\hline \multicolumn{9}{|c|}{ Personal share of household income } \\
\hline$\geq 75 \%$ & 1382 & 37 & 1.35 & $1.19-1.54$ & & & 1.25 & $1.07-1.45$ \\
\hline
\end{tabular}

${ }^{a}$ All variables separately (unadjusted model).

${ }^{\mathrm{b}}$ Adjusted for health and demographic variables.

${ }^{\mathrm{c}}$ Adjusted for health, demographic variables, and socioeconomic indicators. 
Table 4. Cox proportional hazards analysis of the influence of individual characteristics and self-perceived health on the likelihood of becoming economically inactive among persons who were continuously employed or became economically inactive $(\mathrm{N}=12529)$ during a follow-up period of ten years. [HR=hazard ratio; $95 \% \mathrm{Cl}=95 \%$ confidence interval.]

\begin{tabular}{|c|c|c|c|c|c|c|c|c|}
\hline & \multirow[b]{2}{*}{ N } & \multirow[b]{2}{*}{$\%$} & \multicolumn{2}{|c|}{ Model 1 a Univariate } & \multicolumn{2}{|c|}{ Model 2 b Multivariate } & \multicolumn{2}{|c|}{ Model $3{ }^{c}$ Multivariate } \\
\hline & & & $\mathrm{HR}$ & $95 \% \mathrm{Cl}$ & $\mathrm{HR}$ & $95 \% \mathrm{Cl}$ & HR & $95 \% \mathrm{Cl}$ \\
\hline $\begin{array}{l}\text { Perceived poor health } \\
\text { Age (years) }\end{array}$ & & $0.94-1.22$ \\
\hline $18-34$ & 5055 & 40 & 1 & & 1 & & 1 & \\
\hline $35-44$ & 4114 & 33 & 0.55 & $0.50-0.61$ & 0.56 & $0.51-0.62$ & 0.59 & $0.53-0.65$ \\
\hline $45-54$ & 2915 & 24 & 0.57 & $0.51-0.64$ & 0.58 & $0.52-0.65$ & 0.63 & $0.56-0.71$ \\
\hline $55-64$ & 445 & 3 & 1.46 & $1.22-1.75$ & 1.53 & $1.28-1.84$ & 1.51 & $1.24-1.83$ \\
\hline Female & 5193 & 41 & 1.45 & $1.34-1.57$ & 1.44 & $1.32-1.56$ & 1.17 & $1.06-1.29$ \\
\hline \multicolumn{8}{|l|}{ Educational level } & $0.71-0.90$ \\
\hline High & 3437 & 28 & 1 & & & & 1 & \\
\hline Intermediate & 6250 & 50 & 1.29 & $1.16-1.43$ & & & 1.09 & $0.98-1.22$ \\
\hline Low & 2787 & 22 & 1.63 & $1.46-1.83$ & & & 1.44 & $1.26-1.63$ \\
\hline \multicolumn{9}{|l|}{ Personal income } \\
\hline$>75 \%$ & & & 1 & & & & 1 & \\
\hline $75-50 \%$ & & & 1.22 & $1.06-1.40$ & & & 1.06 & $0.91-1.22$ \\
\hline $50-25 \%$ & & & 1.80 & $1.59-2.05$ & & & 1.37 & $1.18-1.59$ \\
\hline$<25 \%$ & & & 2.79 & $2.48-3.15$ & & & 2.08 & $1.78-2.43$ \\
\hline \multicolumn{9}{|c|}{ Personal share of household income } \\
\hline$\geq 75 \%$ & 3992 & 33 & 0.89 & $0.82-0.98$ & & & 1.13 & $1.01-1.26$ \\
\hline
\end{tabular}

${ }^{a}$ All variables separately (unadjusted model).

${ }^{\mathrm{b}}$ Adjusted for health and demographic variables.

${ }^{c}$ Adjusted for health, demographic variables, and socioeconomic indicators.

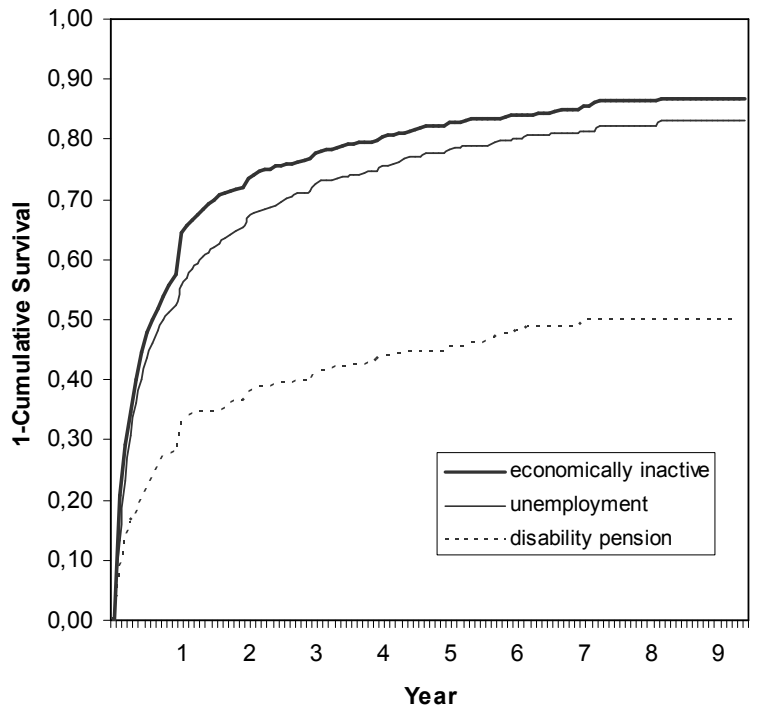

Figure 2. Re-employment after economic inactivity, unemployment or disability pension in a dynamic cohort with enrolment during 1999-2002 and follow-up until 2008 in the Netherlands.

\section{Discussion}

Ill health increased the likelihood of labor force exit into unemployment, disability pension, and early retirement, but was not a determinant of becoming economically inactive. Workers with low socioeconomic status were, even after adjusting for ill health, more likely to leave the labor force, except for early retirement, which was less frequent among low-income workers. Workers with ill health at baseline were less likely to return to work after unemployment or disability pension. Socioeconomic status did not influence re-employment.

These findings are based on information from four samples of Statistics Netherlands' yearly POLS. The annual non-response of the POLS survey was about 35-40\%. Different Statistics Netherlands' studies have shown that persons with a low socioeconomic status may be underrepresented in the survey $(24,25)$. Therefore, the association between socioeconomic status and labor force exit may be underestimated.

A strength of the study is the longitudinal matching of information from a national health survey (POLS) with register information from Statistics Netherlands. The use of register data as a source of information on employment status had two advantages compared to self-reported labor status. First, the definitions of employment status could not be interpreted subjectively by respondents but was defined by main source of income according to the Dutch tax register. Second, the register data provided reliable information about the exact date (month) that an employment transition had occurred during the follow-up period.

A disadvantage of the current analysis is the restriction of self-reported health to one measure. However, the assessment of self-perceived health has been found to be useful in evaluating health status in large epidemiologic studies and has been shown to be a strong predictor of mortality in high as well as low socioeconomic groups 
Table 5. Multivariate Cox proportional hazards analysis of the influence of individual characteristics and self-perceived health on the likelihood of re-employment after unemployment, disability pension or economic inactivity during a follow-up period of ten years. [HR=hazard ratio; $95 \% \mathrm{Cl}=95 \%$ confidence interval.]

\begin{tabular}{|c|c|c|c|c|c|c|c|c|c|c|c|c|}
\hline & \multicolumn{4}{|c|}{$\begin{array}{l}\text { Re-employment after unemployment } \\
\qquad N=1264\end{array}$} & \multicolumn{4}{|c|}{$\begin{array}{l}\text { Re-employment after disability } \\
\qquad \mathrm{N}=398\end{array}$} & \multicolumn{4}{|c|}{$\begin{array}{l}\text { Re-employment after economic inactivity } \\
\qquad N=2411\end{array}$} \\
\hline & $\mathrm{N}$ & $\%$ & $\mathrm{HR}$ & $95 \% \mathrm{Cl}$ & $\mathrm{N}$ & $\%$ & $\mathrm{HR}$ & $95 \% \mathrm{Cl}$ & $\mathrm{N}$ & $\%$ & $\mathrm{HR}$ & $95 \% \mathrm{Cl}$ \\
\hline Perceived poor health & 257 & 20 & 0.75 & $0.63-0.90$ & 207 & 52 & 0.62 & $0.46-0.84$ & 280 & 12 & 0.88 & $0.75-1.02$ \\
\hline $18-34$ & 491 & 39 & 1 & & 83 & 21 & 1 & & 1235 & 51 & 1 & \\
\hline $35-44$ & 351 & 28 & 0.83 & $0.70-0.97$ & 92 & 23 & 0.70 & $0.47-1.06$ & 606 & 25 & 0.85 & $0.75-0.95$ \\
\hline $45-54$ & 336 & 27 & 0.44 & $0.36-0.54$ & 156 & 39 & 0.49 & $0.33-0.72$ & 441 & 18 & 0.56 & $0.48-0.64$ \\
\hline $55-64$ & 86 & 7 & 0.13 & $0.08-0.20$ & 67 & 17 & 0.19 & $0.10-0.35$ & 129 & 5 & 0.16 & $0.11-0.22$ \\
\hline Female & 573 & 45 & 0.85 & $0.73-0.99$ & 206 & 52 & 0.95 & $0.66-1.38$ & 1198 & 50 & 0.83 & $0.75-0.93$ \\
\hline $\begin{array}{l}\text { Married/living } \\
\text { together }\end{array}$ & 1009 & 80 & 0.99 & $0.82-1.20$ & 321 & 81 & 1.98 & $1.21-3.26$ & 1953 & 82 & 0.84 & $0.74-0.96$ \\
\hline \multicolumn{13}{|l|}{ Educational level } \\
\hline High & 275 & 22 & 1 & & 84 & 21 & 1 & & 529 & 22 & 1 & \\
\hline Intermediate & 581 & 46 & 0.90 & $0.76-1.08$ & 169 & 43 & 1.13 & $0.73-1.76$ & 1210 & 50 & 1.11 & $0.97-1.26$ \\
\hline Low & 407 & 32 & 0.87 & $0.71-1.06$ & 140 & 36 & 0.69 & $0.42-1.14$ & 662 & 28 & 1.08 & $0.94-1.25$ \\
\hline \multicolumn{13}{|l|}{ Personal income } \\
\hline$>75 \%$ & 254 & 20 & 1 & & 72 & 18 & 1 & & 372 & 16 & 1 & \\
\hline $75-50 \%$ & 272 & 22 & 1.12 & $0.90-1.41$ & 96 & 24 & 0.94 & $0.56-1.57$ & 455 & 19 & 1.01 & $0.86-1.20$ \\
\hline $50-25 \%$ & 334 & 27 & 1.27 & $1.01-1.60$ & 124 & 31 & 0.95 & $0.58-1.55$ & 665 & 28 & 0.96 & $0.81-1.13$ \\
\hline$<25 \%$ & 401 & 32 & 1.16 & $0.91-1.48$ & 106 & 27 & 0.86 & $0.49-1.51$ & 911 & 38 & 0.95 & $0.79-1.13$ \\
\hline \multicolumn{13}{|l|}{$\begin{array}{l}\text { Personal share of } \\
\text { household income }\end{array}$} \\
\hline$\geq 75 \%$ & 442 & 35 & 0.91 & $0.77-1.07$ & 140 & 35 & 1.35 & $0.92-1.98$ & 699 & 29 & 0.96 & $0.85-1.09$ \\
\hline
\end{tabular}

(23). In addition, a Dutch longitudinal study showed that the predictive value of self-assessed health for mortality was consistent across four educational levels and not influenced by self-reported presence of chronic diseases (26). Unfortunately, no consistent information was available on specific diseases during 1999-2002, due to a revision of the POLS questionnaire in 2001. Hence, it was not possible to evaluate whether the presence of particular diseases largely explained the role of health in entering or leaving the workforce.

The follow-up period of ten years gives insight into determinants of labor force exit as well as re-employment of the Dutch working population. This study provides insight into the different pathways out of the labor force and the (time-dependent) likelihood of re-employment. Health status and individual and household characteristics were measured at baseline. During the follow-up period of ten years, employment status was registered monthly, but changes in determinants were not measured. The occurrence of workers' health problems during the follow-up period may have influenced employment transitions, especially the onset of health problems that were not reflected in the initial self-assessed health. The implications for the current findings are difficult to predict, but the results for poor health on labor force exit were very similar when limiting the follow-up period to one year. A longitudinal study among workers in different European countries with different follow-up periods before labor force exit showed that, for the majority of workers, self-reported poor health seemed to be an accumulator of prolonged health complaints rather than acute health problems (17).

This study showed that health is an important predictor of labor force exit into unemployment, early retirement, or disability pension. This finding is in concordance with other studies, showing that health is an important determinant of early retirement $(16,18,27$, $28)$, unemployment $(29,30)$ and disability pension (6). However, this study did not show that health status influenced the transition into economic inactivity. Females, younger (18-34 years) and older (55-64 years) workers, and workers with a low level of education were more likely to leave the labor force into economic inactivity. A study of Statistics Netherlands found that women with low levels of education more often left the labor force to take care of their families compared to those with a higher education (31). Other studies also found that, in the Netherlands, the labor force participation of mothers with lower education levels is much lower than among those with high levels of education (32, 33). An Australian study among older women found that transitions into informal caregiving was followed by a decrease in labor force participation, whereas health status did not influence labor force participation among caregivers (34).

Additional analyses on gender differences in the role of poor health on labor force transitions showed that poor health was a less important determinant of disability pension among women (HR 5.02) than men (HR 7.82). There were no gender differences in the role 
of poor health on other pathways out of the labor force. In addition, there were no gender differences in the role of education on labor force exit. However, among male workers, a low income increased the likelihood of disability (HR 2.98) and decreased the likelihood of early pension (HR 0.13), whereas income was not associated with disability or early pension among female workers.

There is ample evidence for socioeconomic differences in health (3-7). The current study showed that, even after adjusting for ill health, workers with low socioeconomic status were more likely to be displaced from the workforce. This was in congruence with a recently published Norwegian study, which showed that there was a socioeconomic gradient in disability pension similar to the well-known socioeconomic gradient in health (15). Our study suggests that the findings concerning a socioeconomic gradient in disability pension can also be generalized to labor force exit due to unemployment and early retirement.

The current study showed that, although educational level and income were correlated, both measures had an independent influence on the likelihood of labor force exit and re-employment. Geyer et al (35) has argued that education and income cannot be used interchangeably in social epidemiology since they measure different phenomena and tap into different causal mechanisms. In general, a low socioeconomic status increased the likelihood of labor force exit. However, workers with a low or intermediate income were less likely to leave the labor force due to early retirement. Early retirement is usually possible at the expense of a lower income in the years after retirement, compared to the income during the years of working. Therefore, low-income workers may not be able to afford early retirement.

In the present study, the negative effect of poor health on labor force participation was not influenced by socioeconomic status as in all socioeconomic groups poor health was an important determinant of labor force exit. This finding was in contrast with the results from a European longitudinal study showing that poor health was a risk factor for becoming unemployed or retiring especially among highly educated workers (17). Apparently in the Netherlands, workers with high as well as low socioeconomic status are equally protected against health-related workforce exclusion. On the other hand, differences in employment conditions of workers with high versus low socioeconomic position may influence the ability of workers with poor health to continue working. Further research is needed to elaborate the potential interactions between poor health and working conditions in different socioeconomic groups.

Persons who had poor health before exiting the labor force were less likely to re-enter paid employment after unemployment and disability pension. This is in congruence with findings from other studies showing that poor mental (29) as well as physical (19) health reduced the likelihood of re-entering paid employment.

In the current study, educational level as well as personal income seemed to have no influence on the likelihood of re-employment. However, the small number of persons in some groups (eg, re-employment after disability pension; $\mathrm{N}=178$ ) may have limited the possibilities to find an association. Other studies among unemployed persons in the Netherlands found that persons with a low level of education were less likely to find paid employment $(19,36)$. The current study concerned re-employment of non-employed persons with a recent history of employment because all participants were employed at the beginning of the study. Socioeconomic differences in entering paid employment may be smaller among persons with a recent employment history. Non-employed persons with a low socioeconomic status may be more likely to enter paid employment into poor-quality or temporary jobs (37). Entering the labor force through temporary jobs decreases the duration of the non-employment period (38). However, temporary jobs with low wages may result in more frequent unemployment episodes during working life (37). Further research needs to be done to confirm the findings of the current study and give more insight into employment conditions and contracts after re-entering paid employment.

The current study showed that re-entering paid employment occurred for half of the economically inactive and unemployed persons within approximately six months. In contrast, persons with a disability pension faced long spells of non-employment. Approximately $25 \%$ of the persons on disability pension re-entered paid employment within six months, whereas even after seven years only half of the persons on disability pension had re-entered the labor force. The likelihood of becoming or staying unemployed may also depend on social and labor market policies. The contribution of the different pathways (early retirement, disability pension, unemployment, economic inactivity) out of the labor force may depend on the country-specific regulations and, thus, differ between countries. In this population, ill health was not a determinant of becoming economically inactive. In the Netherlands, for those workers with health problems, a disability pension was a more favorable pathway out of the labor force than becoming economically inactive. In other countries with different eligibility criteria and benefits, the role of ill health in becoming economically inactive may be of importance. In addition, in the Netherlands $<10 \%$ of the disabled persons have labor as their main source of income, whereas in Sweden this proportion amounts to $>50 \%$ (39). Therefore, one should be careful with generalizing the current findings from the Netherlands to other countries with different welfare state regimes (40). However, as described earlier, socioeconomic differences in labor 
force exit have also been found in other European studies $(9,11,15,17)$.

The finding that the likelihood of re-employment decreased with increasing duration of the non-employment period down to approximately zero after seven years of non-employment has important policy implications. It is important to be aware of the time dynamics of the likelihood of entering paid employment when return-to-work activities are employed. Based on these results, it can be expected that re-employment of persons who are long-term non-employed ( $>7$ years) will be a tough challenge, and, therefore, efforts should be made to prevent onset of long-term non-employment.

In conclusion, ill health is an important determinant for entering and maintaining paid employment. There are socioeconomic differences in labor force exit, with low socioeconomic groups being more likely to become unemployed or economically inactive or to go on disability pension. Policies to improve labor force participation, especially among low socioeconomic workers, should protect workers with health problems against exclusion from the labor force.

The views expressed in this paper are those of the authors and do not necessarily reflect the policies of Statistics Netherlands

\section{References}

1. Ilmarinen JE. Aging workers. Occup Environ Med. 2001;58(8):546-52. http://dx.doi.org/10.1136/oem.58.8.546.

2. Van Nimwegen N, Beets G. Social Situation Observatory. Demography Monitor 2005. Demographic trends, socioeconomic impacts and policy implications in the European Union. Report no. 72, ISBN-10: 90-8780-003-7. http://www.nidi.knaw.nl/Content/NIDI/output/reports/nidireport-72.pdf. Netherlands Interdisciplinary Demographic Institute. 2006.

3. Cai L, Kalb G. Health status and labour force participation: evidence from Australia. Health Econ. 2006;15(3):241-61. http://dx.doi.org/10.1002/hec.1053.

4. Alavinia SM, Burdorf A. Unemployment and retirement and ill-health: a cross-sectional analysis across European countries. Int Arch Occup Environ Health. 2008;82(1):39-45. http:// dx.doi.org/10.1007/s00420-008-0304-6.

5. Bartley M. Unemployment and ill health: understanding the relationship. Journal of epidemiology and community health. 1994;48(4):333-7. http://dx.doi.org/10.1136/jech.48.4.333.

6. Karpansalo M, Manninen P, Kauhanen J, Lakka TA, Salonen JT. Perceived health as a predictor of early retirement. Scand J Work Environ Health. 2004;30(4):287-92. http://dx.doi. org/10.5271/sjweh.796.

7. Bound J, Schoenboum M, Stinebrickner TR, etal. The dynamic effects of health on the labor force transitions of older workers. Labour Economic. 1999;6:179-202. http://dx.doi. org/10.1016/S0927-5371(99)00015-9.

8. Kristensen P. Inequalities in health, social causation and the role of occupation. Scand J Work Environ Health. 2008 Aug;34(4):235-8. http://dx.doi.org/10.5271/sjweh.1273.

9. Haukenes I, Mykletun A, Knudsen AK, Hansen HT, Maeland JG. Disability pension by occupational class--the impact of work-related factors: the Hordaland Health Study Cohort. BMC Public Health. 2011;11:406. http://dx.doi. org/10.1186/1471-2458-11-406.

10. Gravseth HM, Bjerkedal T, Irgens LM, Aalen OO, Selmer $\mathrm{R}$, Kristensen P. Life course determinants for early disability pension: a follow-up of Norwegian men and women born 1967-1976. Eur J Epidemiol. 2007;22(8):533-43. http:// dx.doi.org/10.1007/s10654-007-9139-9.

11. Bruusgaard D, Smeby L, Claussen B. Education and disability pension: a stronger association than previously found. Scand J Public Health. 2010;38(7):686-90. http://dx.doi. org/10.1177/1403494810378916.

12. Krokstad S, Westin S. Disability in society-medical and non-medical determinants for disability pension in a Norwegian total county population study. Soc Sci Med. 2004;58(10):1837-48. http://dx.doi.org/10.1016/S02779536(03)00409-X.

13. Krokstad S, Johnsen R, Westin S. Social determinants of disability pension: a 10 -year follow-up of 62000 people in a Norwegian county population. Int $\mathrm{J}$ Epidemiol. 2002;31(6):1183-91. http://dx.doi.org/10.1093/ ije/31.6.1183.

14. Karlsson NE, Carstensen JM, Gjesdal S, Alexanderson KA. Risk factors for disability pension in a population-based cohort of men and women on long-term sick leave in Sweden. Eur J Public Health. 2008;18(3):224-31. http://dx.doi.org/10.1093/ eurpub/ckm128.

15. Ostby KA, Orstavik RE, Knudsen AK, Reichborn-Kjennerud T, Mykletun A. Health problems account for a small part of the association between socioeconomic status and disability pension award. Results from the Hordaland Health Study. BMC Public Health. 2011;11:12. http://dx.doi. org/10.1186/1471-2458-11-12.

16. van den Berg TI, Elders LA, Burdorf A. Influence of health and work on early retirement. J Occup Environ Med. 2010;52(6):576-83. http://dx.doi.org/10.1097/ JOM.0b013e3181de8133.

17. Schuring M, Burdorf L, Kunst A, Mackenbach J. The effects of ill health on entering and maintaining paid employment: Evidence in European countries. J Epidemiol Community Health. 2007;61(7):597-604. http://dx.doi.org/10.1136/ jech.2006.047456.

18. Nilsson K, Hydbom AR, Rylander L. Factors influencing the decision to extend working life or retire. Scand J Work Environ Health. 2011;37(6):473-80. http://dx.doi.org/10.5271/ sjweh.3181.

19. Schuring M, Mackenbach J, Voorham T, Burdorf A. The 
effect of re-employment on perceived health. J Epidemiol Community Health. 2011;65(7):639-44. http://dx.doi. org/10.1136/jech.2009.103838.

20. Pattani S, Constantinovici N, Williams S. Predictors of reemployment and quality of life in NHS staff one year after early retirement because of ill health; a national prospective study. Occup Environ Med. 2004;61(7):572-6. http://dx.doi. org/10.1136/oem.2003.011817.

21. Claussen B, Bjorndal A, Hjort PF. Health and re-employment in a two year follow up of long term unemployed. Journal of Epidemiology and Community Health. 1993;47(1):14-8. http://dx.doi.org/10.1136/jech.47.1.14.

22. Otten F, Winkels J. Toelichting op het Permanent Onderzoek Leefsituatie [Permanent Survey on Living Conditions]. Maandbericht gezondheid 1998/4. Voorburg/Heerlen: Centraal Bureau voor de Statistiek (Statistics Netherlands); 1998.

23. Burstrom B, Fredlund P. Self rated health: Is it a good a predictor of subsequent mortality among adults in lower as well as in higher social classes? J Epidemiol Community Health. 2001;55(11):836-40. http://dx.doi.org/10.1136/ jech.55.11.836.

24. te Riele S. Vertekening door non-respons -Hoe nauwkeurig zijn de uitkomsten van persoonsenquetes? [Selective nonrespons-How reliable are the outcomes of surveys?]. Sociaaleconomische maandstatistiek 2002/4. Voorburg/Heerlen: Centraal Bureau voor de Statistiek (Statistics Netherlands); 2002 .

25. Bethlehem J, Schouten B. Nonrespons Analysis of the Integrated Survey on Living Conditions (POLS). Discussion paper 04004. Voorburg/Heerlen: Centraal Bureau voor de Statistiek (Statistics Netherlands); 2004.

26. Huisman M, van Lenthe F, Mackenbach J. The predictive ability of self-assessed health for mortality in different educational groups. Int J Epidemiol. 2007;36(6):1207-13. http://dx.doi.org/10.1093/ije/dym095.

27. Olesen SC, Butterworth P, Rodgers B. Is poor mental health a risk factor for retirement? Findings from a longitudinal population survey. Soc Psychiatry Psychiatr Epidemiol. 2012 May;47(5):735-44.

28. Friis K, Ekholm O, Hundrup YA, Obel EB, Gronbaek M. Influence of health, lifestyle, working conditions, and sociodemography on early retirement among nurses: the Danish Nurse Cohort Study. Scand J Public Health. 2007;35(1):23-30. http://dx.doi.org/10.1080/14034940600777278.

29. Butterworth P, Leach LS, Pirkis J, Kelaher M. Poor mental health influences risk and duration of unemployment: a prospective study. Soc Psychiatry Psychiatr Epidemiol. 2011 Epub Date 2011/06/18.
30. Jusot F, Khlat M, Rochereau T, Serme C. Job loss from poor health, smoking and obesity: a national prospective survey in France. J Epidemiol Community Health. 2008;62(4):332-7. http://dx.doi.org/10.1136/jech.2007.060772.

31. Bierings H, Souren M. Minder werken na geboorte kind [Decreasing labour force participation after child birth]. Sociaaleconomische trends, 3e kwartaal 2011 Statistisch kwartaalblad over arbeidsmarkt, sociale zekerheid en inkomen. 2011:21-4. Den Haag/Heerlen: Centraal Bureau voor de Statistiek. Available from http://www. cbs.n1/NR/rdonlyres/DFC60B4B-CB83-4FF0-9BE99D0B7C2A1A6D/0/2011k3v4p21art.pdf.

32. van Wel F, Knijn T. Transitional phase or a new balance? Working and caring by mothers with young children in the Netherlands. Journal of Family Issues. 2006;27(5):633-51. http://dx.doi.org/10.1177/0192513X05284858.

33. Cloïn M, Keuzenkamp S, Plantenga J. A matter of culture and cost? A comparison of the employment decisions made by mothers with a lower, intermediate and higher level of education in the Netherlands. Work, employment and Society. 2011;25(3):468-86. http://dx.doi. org/10.1177/0950017011407963.

34. Berecki-Gisolf J, Lucke J, Hockey R, Dobson A. Transitions into informal caregiving and out of paid employment of women in their 50s. Soc Sci Med. 2008;67(1):122-7. http:// dx.doi.org/10.1016/j.socscimed.2008.03.031

35. Geyer S, Hemstrom O, Peter R, Vagero D. Education, income, and occupational class cannot be used interchangeably in social epidemiology. Empirical evidence against a common practice. J Epidemiol Community Health. 2006;60(9):804-10. http://dx.doi.org/10.1136/jech.2005.041319.

36. van Gaalen R, Sanders J, Smits W, Ybema JF. Dynamiek op de Nederlandse arbeidsmarkt. De focus op kwetsbare groepen. ISBN: 978-90-357-1937-8. Den Haag/Heerlen: Centraal Bureau voor de Statistiek; 2011.

37. Hershey AM, Pavetti LA. Turning job finders into job keepers. Future Child. 1997;7(1):74-86. http://dx.doi. org/10.2307/1602579.

38. De Graaf-Zijl M, Van den Berg GJ, Heyma A. Stepping stones for the unemployed: The effect of temporary jobs on the duration until regular work. IZA; 2004. Available from http:// www.ifau.se/Upload/pdf/se/2004/wp04-19.pdf

39. OECD. Transforming disability into ability. Policies to promote work and income security for disabled people. Paris: OECD; 2003.

40. Bambra C. Going beyond The three worlds of welfare capitalism: regime theory and public health research. J Epidemiol Community Health. 2007;61(12):1098-102. http:// dx.doi.org/10.1136/jech.2007.064295.

Received for publication: 8 March 2012 